\title{
THE CONCEPT OF THE ARCHIPELAGIC PROVINCE AND ARCHIPELAGIC STATE IN THE PERSPECTIVE OF NATIONAL AND INTERNATIONAL LAW
}

\author{
Muhammad Risnain \\ Faculty of Law, Universitas Mataram, Indonesia, \\ E-mail: risnain82@gmail.com
}

Submitted: June 18, 2021; Reviewed: July 12, 2021; Accepted: August 10, 2021

\begin{tabular}{ll}
\hline \multicolumn{1}{c}{ Article Info } & Abstract \\
\hline Keywords: & The concept of an archipelagic province in law number 23 of \\
Characteristic, Archipelagic, & 2014 is interesting, especially international law of the sea and \\
Province. & Indonesian national law. This research is due to the concept of an \\
DOI: & archipelagic State's special treatment, which is a concept derived \\
from the 1982 United Nations Convention on the Law of the Sea \\
(UNCLOS). This research accommodates the state's interests with \\
special conditions for States that are geographical, social, \\
political, and economic conditions by fulfilling the 1982 \\
UNCLOS. The state is a subject of the international, but the \\
archipelagic province receives special treatment from the central \\
government in DAU and DAK. The problem in this research is \\
how the concept of an archipelagic province and state is based on \\
national and international law? The research method used is \\
normative juridical research based on the applicable laws and \\
regulations. The analysis is carried out using a descriptive method \\
that explains the concept of an archipelagic province and state \\
from the perspective of national and international law. The \\
archipelagic state's international and national law concept cannot \\
be applied to mutatis mutandis. The criteria for an archipelagic \\
state as an intrinsic geographical, economic, defense and security, \\
and political unit have historically been regarded as such. The \\
1982 UNCLOS and national laws cannot be applied in \\
determining the criteria for an archipelagic province. According \\
to the elucidation of Law Number 23 of 2014 concerning regional \\
government, the archipelagic province based on geographical and \\
cultural conditions is a moderate concept. This concept is \\
beneficial in determining the characteristics of an archipelagic \\
province.
\end{tabular}

\section{A. Introduction}

The archipelagic province is associated with various aspects, including regional autonomy, a unitary state, an archipelago perspective, international law, and national law. The inclusion of the Bill of Law or Rancangan Undang-Undang (RUU) on Government Administration in the Archipelago province in the 2009-2014 national legislation program or Program Legislasi Nasional (Prolegnas) and the 2014-2019 Prolegnas, from a formal legal perspective, has made a critical bill to be discussed and enacted to be a law. Although the 
Indonesia House of Representatives and the President have not ratified it into law, this bill leaves a problem with the substance regulated in it. ${ }^{1}$

The archipelagic province concept needs to be studied from a unitary state with a vertical power system distribution. This distribution is implemented through the principle of decentralization, both through regional autonomy and de-concentration. These two things will undoubtedly be conceptually contradictory, the decentralization system with regional autonomy. ${ }^{2}$ De-concentration is a policy choice that the government and parliament have taken to accommodate regional interests within the framework of the Unitary State of the Republic of Indonesia. Still, a particular government system for archipelagic regions will conflict with the uniformity of autonomy regardless of a geographic area. ${ }^{3}$

A province with archipelagic characteristics has been regulated in Article 28 to 30 Law Number 23 of 2014 concerning regional governance. This law regulates special treatment for archipelagic provinces, which are different from other provinces in Indonesia. The special treatment in question includes, firstly, the authority to manage natural resources, ${ }^{4}$ secondly, a special assignment from the central government to the archipelagic province in the marine sector, ${ }^{5}$ third, special policy for a general allocation fund (Dana Alokasi Umum/DAU) and special allocation fund (Dana Alokasi Khusus/DAK).

In addition to the regulatory issues above, special arrangements for archipelagic provinces are currently still the aspirations of various provinces that geographically have more than two islands. Two problems underlie the idea of forming an archipelagic province in Indonesia. First, several provinces are still fighting for special treatment for provinces with archipelagic characteristics such as North Sulawesi, North Maluku, Maluku, Bangka Belitung, and Riau Islands, West Nusa Tenggara, and East Nusa Tenggara. Secondly, a province demand wants to be independent, such as establishing Sumbawa Province from West Nusa Tenggara Province, the Buton Islands province in Southeast Sulawesi, the Nias Islands province in North Sumatra, and the discourse of splitting the province of East Nusa Tenggara into three provinces.

The concept of an archipelagic province in law number 23 of 2014 is interesting, especially international law of the sea and Indonesian national law. The concept of special treatment of an archipelagic State is derived from the 1982 United Nations Convention on the Law of the Sea (UNCLOS), which accommodates the special conditions for States' geographical, social, political, and political-economic conditions. Due to geographical conditions, the archipelagic state receives special treatment from the central government in DAU and DAK. This particular treatment fulfills the 1982 UNCLOS, while the concept of an archipelagic province is based on a province with archipelagic characteristics.

The problem in this research is how the concept of an archipelagic province and state is based on national and international law. Therefore, this study will examine and analyze the laws, regulations, and decisions related to legal issues in this research. The research method used is normative juridical research based on the applicable laws and regulations. ${ }^{6}$ The

\footnotetext{
${ }^{1}$ Nikmatul Huda, Desentralisasi Asimetris Dalam NKRI: Kajian Terhadap Daerah Istimewa, Daerah Khusus Dan Otonomi Khusus (Bandung: NusaMedia, 2014).

2 Bagir Manan, Menyongsong Fajar Otonomi Daerah, 5th ed. (Yogyakarta: PSH FH UII, 2005).

3 Bagir Manan, Hubungan Antara Pusat Dan Daerah Menurut UUD 1945 (Jakarta: Pustaka Sinar Harapan, 1994).

4 Mudiyati Rahmatunnisa, Reginawanti Hindersah, and Tri Hanggono Achmad, "Why Regions with Archipelagic Characteristics in Indonesia Also Need Asymmetric Decentralization?," Jurnal Bina Praja 10, no. 2 (2018): 259, https://doi.org/10.21787/jbp.10.2018.251-261.

5 Zainuri, "Pembentukan Hukum Dan Perlakuan Khusus Wilayah Provinsi Kepulauan Dalam Sistem Pemerintahan Daerah Di Indonesia," Perspektif Hukum 18, no. 1 (2019): 86, https://doi.org/10.30649/ph.v18i1.

6 Kornelius Benuf and Muhamad Azhar, "Metodologi Penelitian Hukum Sebagai Instrumen Mengurai Permasalahan Hukum Kontemporer," Gema Keadilan 7, no. 1 (2020): 23, https://doi.org/10.14710/gk.7.1.20-33.
} 
analysis is carried out using a descriptive method that explains the concept of an archipelagic province and state from the perspective of national and international law. Data were collected from various literature to obtain relevant legal instruments and secondary research sources, such as books and national or international journals, which then will be analyzed qualitatively. $^{7}$

\section{B. Discussion}

\section{Archipelagic State in the Perspective of International Law of the Sea}

As reference material, we quote Article 46 of the 1982 United Nations Convention on the Law of the Sea (UNCLOS) concerning the Archipelagic States as follows: ${ }^{8}$

a) "archipelagic State" means a State constituted wholly by one or more archipelagos and may include other islands;

b) "archipelago" means a group of islands, including parts of islands, interconnecting waters, and other natural features which are so closely interrelated that such islands, waters, and other natural features form an intrinsic geographical, economic, and political entity, or which historically have been regarded as such.

Based on the articles above, an archipelagic state consists of one or more islands and may include other islands. ${ }^{9}$ Archipelago means a group of islands including parts of islands, the waters between them, and other scientific forms that are so closely related that the islands, waters, and other natural features constitute an intrinsic geographical, economic, and political entity historically regarded as such. ${ }^{10}$

The recognition of an archipelagic state as a separate regime in the 1982 UNCLOS has implications for the legal status of archipelagic waters. According to Etty R Agoes, three legal implications arise from a country becoming an archipelagic state: the sovereignty of an archipelagic state over the waters enclosed by archipelagic waters regardless of the depth and distance from the coast. The sovereignty includes the air space above it, the seabed and the land below it, and the natural resources contained therein. The three archipelagic countries are sui generis (special regimes) because apart from being archipelagic waters, it is also recognized in the existence of innocent passage in archipelagic waters.

Besides giving rights inherent in the archipelagic state, the archipelagic state also creates legal obligations. According to the 1982 UNCLOS, there are obligations for archipelagic countries, namely:

a) Respect applicable international treaties and recognize the traditional fishing rights of neighboring countries directly adjacent to each other.

b) Respecting marine cables installed in other countries, permitting maintenance and replacement of these cables.

c) Respect the right of innocent passage of ships of all countries.

d) Respect the right of archipelagic waters lane passage for all types of foreign ships and aircraft.

\footnotetext{
${ }^{7}$ Muhammad Insan Tarigan Raisha Hafandi, "Equal Access to the Vaccination of Covid-19 in Southeast Asia: Can ASEAN Be a Catalyst?," Hasanuddin Law Review 7, no. 2 (2021): 121, https://doi.org/10.20956/halrev.v7i2.2875.

${ }^{8}$ Evan A. Laksmana and Ristian A. Supriyanto, "Abandoned at Sea: The Tribunal Ruling and Indonesia's Missing Archipelagic Foreign Policy," Asian Politics \& Policy 10, no. 2 (2018): 305, https://doi.org/10.1111/aspp.12393.

9 Yety Rochwulaningsih et al., "Marine Policy Basis of Indonesia as a Maritime State: The Importance of Integrated Economy,” Marine Policy 108 (2019): 2, https://doi.org/10.1016/j.marpol.2019.103602.

${ }^{10}$ Bita Parga Zen, "The Concept of Big Data Analysis for Maritime Information on Indonesian Waters Using KMeans Algorithm," Journal of Informatics, Information System, Software Engineering and Applications 3, no. 2 (2021): 44, https://doi.org/10.20895/INISTA.V3I2.
} 
In addition to these obligations in archipelagic waters, the state must recognize the right of innocent passage and archipelagic waters lane passage for foreign ships. It also recognizes the right of passage of communication and other interests of the nearest neighboring country. ${ }^{11}$

According to Article 47 Paragraph 1 of the 1982 United Nations Convention on the Law of the Sea (UNCLOS), archipelagic countries have the right to draw an archipelagic baseline as the basis for measuring their territorial waters from the farthest points of their outermost islands. ${ }^{12}$ As a consequence of Indonesia as an archipelagic country in the 1982 UNCLOS, Indonesia has sovereignty over an area of 3.2 million $\mathrm{km}^{2}$ of waters. The waters include 2.9 million $\mathrm{km}^{2}$ of archipelagic waters and 0.3 million $\mathrm{km}^{2}$ of the territorial sea. In addition, Indonesia has the exclusive right to exploit marine resources and various interests covering an area of $2.7 \mathrm{~km}^{2}$ in EEZ waters (up to 200 miles from the baseline). ${ }^{13}$ To determine the characteristics of an archipelagic state, it can be seen in various laws and regulations that Indonesia has issued to strengthen the recognition of Indonesia as an archipelagic state. In 1957 Prime Minister Djuanda issued a necessary unilateral declaration to the international community.

"All waters around, between, and connecting the islands that are part of the State of Indonesia regardless of the extent or width are natural parts of the land area of the State of Indonesia and thus part of the interior or national waters under absolute sovereignty. Peaceful traffic in these inland waters for foreign ships is guaranteed as long as it does not conflict with/disturb the sovereignty and safety of the State of Indonesia. Determination of the boundaries of the territorial sea shelf (12 miles wide) is measured from the line connecting the outermost endpoints on the islands of the State of Indonesia. The provisions mentioned above will be regulated as soon as possible by law".

The declaration gave birth to three characteristics of an archipelagic state: first, geographically, an archipelagic country covers the waters around, between, and connects the islands of the Indonesian state. Secondly, the waters do not consider the area or width as natural parts of the archipelago, the land area of the Indonesian state, and thus part of the interior or national waters; third, the status of state sovereignty over the archipelagic state is under the absolute sovereignty of the Indonesian state. ${ }^{14}$

The Djuanda Declaration contained a unilateral statement by the Indonesian people related to the claim of the Indonesian people to the sea area, which was not necessarily accepted as an international legal regime at that time. The 1957 Djuanda declaration was later recognized as an international legal regime when in Montego Bay, Jamaica, in 1982, the countries under the United Nations signed the 1982 UNCLOS text. The Djuanda Declaration in the context of international law can be seen in two perspectives; first, the Djuanda declaration is a statement by Indonesia as a newly independent country to the international community regarding the territorial conception (unilateral action) to secure the interests of defense and security. National security is also the national economic interest. Second, Djuanda's declaration is a political statement of the Indonesian nation towards the territorial concept, which later became the forerunner of archipelago insight. ${ }^{15}$

11 Atje Misbach Muhjidin, Status Hukum Perairan Kepulauan Indonesia Dan Hak Lintas Kapal Asing (Bandung: Alumni, 1993).

${ }^{12}$ C. F. Amerasinghe, "The Problem of Archipelagoes in the International Law of the Sea," International and Comparative Law Quarterly 23, no. 3 (1974): 541, https://www.jstor.org/stable/757887.

${ }^{13}$ Mochtar Kusumaatmadja, Konsepsi Hukum Negara Nusantara Pada Konferensi Hukum Laut 1982 (Bandung: Alumni, 2003).

14 M. Budiarto, Wawasan Nusantara Dalam Peraturan Perundang-Undangan Negara Republic Indonesia (Jakarta: Ghalia Indonesia, 1980).

15 Arief Adi Purwoko, "The Material of Wawasan Nusantara as Indonesian Geopolitic Note and the Implementation in Islamic State University," At-Turats: Jurnal Pemikiran Pendidikan Islam 14, no. 1 (2020): 86, https://doi.org/10.24260/at-turats.v14i1.1785. 
Since the Declaration announcement on December 13, 1957, the Indonesian government has continued to fight for the legal conception of an archipelagic state to be accepted and recognized by the international community. This struggle has finally resulted in universal recognition by the international community, namely the acceptance of the regulation on the principles and legal regime of the archipelagic state in Chapter IV of the 1982 United Nations Convention on the Law of the Sea. The Law Number 17 of 1985 concerning Ratification of the United Nations Convention on the Law of the Sea.

The change in the position of the Republic of Indonesia as an archipelagic country has vast implications not only for national interests but also for international interests in Indonesian waters. International recognition of Indonesia as an archipelagic state comes with a consequence. Indonesia must respect the rights of the international community in the waters that are now national waters, especially the right of peaceful passage and the right of archipelagic waters lane passage for foreign ships.

After the international community is convinced that with this action, Indonesia does not intend to reduce the rights of the legal shipping world, and a balance is reached between Indonesia's desire to secure its territorial integrity and control the natural resources contained therein. However, the world's interest in international shipping because the international community finally accepted the principle of this archipelagic state.

From a constitutional law point of view, the Declaration dated December 13, 1957, and Government Regulation in Lieu of Law No. 4 of 1960 concerning Indonesian Waters was a milestone in the development of the Indonesian state administration that the international community later recognized the Republic of Indonesia as an archipelagic state with the inclusion of the principles and legal regime of an archipelagic state in Chapter IV of the 1982 United Nations Convention on the Law of the Sea. ${ }^{16}$

As stated in the Government Regulation in Lieu of Law Number 4 of 1960 concerning Indonesian Waters, the archipelagic state's principles and legal regime in UNCLOS contain various developments. One of these developments is the recognition of straight archipelagic baselines, the usual baselines, and straight baselines as methods of measuring the Indonesian archipelagic baselines. Based on this measurement method, there are approximately 17,508 islands in the territorial waters of Indonesia.

Thus, the reasons that prompted the Indonesian people to initiate the principle of an archipelagic state and then promulgate it are still relevant today. However, with the development of various interests and activities in Indonesian waters, national and international interests in Indonesian waters need to be organized, secured, and developed in a directed and wise manner following national development goals.

In addition to the interests of defense-security, unity, and economy, environmental protection against the dangers of pollution and its preservation, and the interests of management and utilization in Indonesian waters, it is increasingly urgent. Based on the considerations above, Government Regulation in Lieu of Law No. 4 of 1960 concerning Indonesian Waters needs to be revoked and replaced with a new law because it is no longer under the development of the archipelagic state's legal regime as contained in Chapter IV of the 1982 United Nations Convention on the Law of the Sea.

As a concept, the archipelago insight is a perspective (observation method) of the Indonesian nation based on Pancasila and the 1945 Constitution of itself and its environment in its all-archipelagic existence and its expansion in expressing itself amid its national environment. ${ }^{17}$ This concept has become the perspective of the Indonesian people towards the geographical, geopolitical, and geostrategic environment and the vision of development.

${ }^{16}$ Dino Patti Djalal, The Geopolitics of Indonesia's Maritime Territorial Policy (Jakarta: CSIS, 1996).

17 Sekretariat Pangkolnas, Paparan Tentang Wawasan Nusantara (Pengakuan Perjuangan Dan Implementasinya) (Jakarta: Departemen Pertahanan dan Keamanan RI, 1982). 
Historically, the archipelago insight was known when Prime Minister Djuanda issued a declaration on Indonesian Waters on December 13, 1957. The declaration was later confirmed through Government Regulation in Lieu of Law No. 4 of 1960 and stipulated by Government Regulation in Lieu of Law No. 4 of 1960. The principal will of the government at that time was to replace the colonial legislation, namely Staatsblad 1939-442 concerning the Territorial Zee en Maritime Kringen Ordonnance (TZMKO), which is no longer under developments in international law and the interests of Indonesia's national defense, security and economy. The ordinance determines the sea width of the Indonesian territory as far as three nautical miles calculated from the baseline. Between the islands in the archipelago, there is a high sea. With Government Regulation in Lieu of Law No. 4 of 1960 concerning Indonesian Waters, the calculation of the territorial sea width as far as 12 miles and the status of the waters in and around the islands of the archipelago are subject to the jurisdiction of Indonesia.

In subsequent developments, the spirit of insight into the archipelago became the government's new spirit in claiming other water areas. In 1973, the government claimed the continental shelf with Law No. 1 of 1973 on the continental shelf, and in 1983, the government and the House of Representatives issued Law No. 5 of 1983 on the Exclusive Economic Zone. At the international forum, the Indonesian government continues to struggle to recognize the archipelago's insight. Through 1982 UNCLOS, the international community recognized the archipelago concept proposed by Indonesia. This concept was accepted as one of the regimes in international law of the sea as an archipelagic state. ${ }^{18}$

At the policy level of development planning, the concept of archipelago insight has been accepted in development planning through recognition in the Decrees of the People's Consultative Assembly Number IV/MPR/1973, the Decrees of the People's Consultative Assembly Number IV/MPR/1978, and the Decrees of the People's Consultative Assembly Number II/MPR/1983 concerning Outlines of State Policy. The amendment to the 1945 Constitution of the Republic of Indonesia supports the archipelagic concept through "Wawasan Nusantara". ${ }^{19}$ (Archipelago insight) became part of the territorial concept with special arrangements regarding the state's territory in Article 25A of the 1945 Constitution of the Republic of Indonesia. Boundaries and rights are determined by law. Indonesia's recognition as an archipelago state strengthens the archipelago insight as a territorial concept. The problem is implementing the archipelago insight, which is the geographical, geopolitical, and geostrategic concept.

The characteristics of an archipelagic state have been implied in the definition of Wawasan Nusantara. According to the archipelago perspective, the Indonesian people's perspective is related to territoriality. According to the concept of Wawasan Nusantara, Indonesia's territory is a unitary unit that includes land water (sea) inseparably. This concept has been accommodated as part of national development with the Decree of the People's Consultative Assembly Number II/MPR/1983. The decree is set as an insight in achieving national development, which includes the realization of the archipelago as a political, economic, socio-cultural, and defense-security unit.

Thus, it can be concluded that the criteria for an archipelagic state are a country with the characteristics of the union of land and water (ocean). The concept of unification is a geographical unit and a political, economic, socio-cultural, and defense-security unit. This definition can clarify the island's characteristic's definition determined in Article 25A of the 1945 Constitution of the Republic of Indonesia. ${ }^{20}$

18 Toto Pandoyo, Wawasan Nusantara Dan Implementasinya Dalam UUD 1945 Serta Pembangunan Nasional (Jakarta: Rineka Cipta, 1994).

${ }^{19}$ Wan Usman, "Wawasan Nusantara," in Lokakarya Wasantara Dan Tannas (Lemhannas, 2000).

${ }^{20}$ Lembaga Pertahanan Nasional, Wawasan Nusantara : Naskah Sementara, Lemhanas (Jakarta, 2000). 


\section{Archipelagic Province under Indonesian Law}

Finding the archipelagic state characteristic as one of the special regimes in local government law is essential. An archipelagic province is one of the juridical definitions outlined in the bill of law administering government in the archipelagic region. ${ }^{21}$ It is vital to give this definition to refer to the regulation giving status to the existing province whether it meets the legal requirements to be said to be an archipelagic province with all the rights attached to it or not. ${ }^{22}$

After the geographical and non-geographical criteria of an archipelagic state above, the next question is the criteria for an archipelagic state against an archipelagic province. To answer this question, the researcher departs from the background of the birth of these two demands and the legal consequences that arise for the recognition of these two different legal regimes.

The establishment of an archipelagic state is an aspiration of archipelagic countries pioneered by Indonesia to maintain defense and territorial integrity and strengthen state sovereignty over natural resources at sea. ${ }^{23}$ The aim is to obtain international legal recognition of an archipelagic state as a new legal regime that is sui-generic in international law. This recognition gives rise to the right for countries with archipelagic characteristics to draw straight archipelagic baselines claiming the territorial sea, archipelagic waters, contiguous zone, exclusive economic zone, and continental shelf. ${ }^{24}$ The archipelagic state creates legal obligations to recognize the right of peaceful passage. ${ }^{25}$ In contrast to archipelagic countries, archipelagic provinces are based on the provincial leaders' aspirations regarding the financial balance between the central and regional governments, especially concerning calculating DAU and DAK allocations. ${ }^{26}$

Based on the background of the archipelagic state regime and province, the researcher opined that the state is not mutatis mutandis to the criteria for an archipelagic province. In other words, the requirements to become an archipelagic state are not the same as the requirements for an archipelagic province. The criteria for an archipelagic province have been determined by the Legislation Body of the Indonesian House of Representatives and the Cooperation Agency of the Archipelago Province in the academic text of the bill for the Acceleration of Archipelagic Regional Development. In the Academic Paper, the criteria for the Archipelago Province consist of the following criteria:

a) The area of the sea is larger than the land area;

b) In terms of demographic distribution, the population of the archipelagic region is usually relatively small, and the distribution is uneven;

c) From a socio-cultural perspective, communities in the archipelago are segregated in settlements according to the territory of an island, so it implies a strong sense of attachment to the land, the lifestyle on small islands is harmonized with nature (slow to accept changes);

\footnotetext{
${ }^{21}$ RDH Koesoemahatmadja, Pengantar Ke Arah Sistem Pemerintahan Daerah (Bandung: Binacipta, 1979).

22 Irawan Soejito, Hubungan Pemerintah Pusat Dan Pemerintah Daerah (Jakarta: Rineka Cipta, 1990).

${ }^{23}$ Robert Endi Jaweng, "Kritik Terhadap Desentralisasi Asimetris Di Indonesia," Jurnal Analisis CSIS 40, no. 2 (2011): 162, https://www.kppod.org/article/view?id=2.

${ }^{24}$ Harry Purwanto and Dewa Gede Sudika Mangku, "Legal Instruments of the Republic of Indonesia in Border Management Using the Perspective of Archipelagic State," International Journal of Business, Economics and Law 11, no. 4 (2016): 55, https://www.ijbel.com/wp-content/uploads/2017/01/LAW-112.pdf.

${ }^{25}$ Siti Merida Hutagalung, "Penetapan Alur Laut Kepulauan Indonesia (ALKI): Manfaatnya Dan Ancaman Bagi Keamanan Pelayaran Di Wilayah Perairan Indonesia," Jurnal Asia Pasific Studies 1, no. 1 (2017): 80, https://doi.org/10.33541/japs.v1i1.502.

${ }^{26}$ Muh. Risnain, "Rezim Provinsi Kepulauan Dalam Perspektif Negara Kesatuan Republik Indonesia, Wawasan Nusantara, Dan Otonomi Daerah," Unizar Law Review 3, no. 1 (2020): 103, https://ejournal.unizar.ac.id/index.php/ulr/article/view/247.
} 
d) In terms of the availability of natural resources, it is relatively diverse;

e) In terms of living systems, it is determined by the level of geographical isolation with unique habitat (endemic) and biotic diversity (biodiversity);

f) From a socio-economic point of view, economic activities, types, and degrees of economic dynamics are generally limited and small in scale and have not been adequately supported by distribution and marketing networks;

g) In terms of environment, environmental resources are small, susceptible to change (entropy), prone to natural disasters (waves on the sea surface, dominated by gravitational waves caused by wind; ocean currents are caused by two factors, namely monsoons and tides);

h) From a biogeographical perspective, there is potential for terrestrial and aquatic biodiversity around (small) islands;

i) Almost all of the Archipelago Provinces are located in the territory/region of the State Border, which has a small outermost island.

Based on Presidential Regulation Number 78 of 2005, the small outermost islands in the Archipelago Province are as follow: Riau Islands Province has 20 islands, Maluku Province has 18 islands, North Sulawesi Province has 12 islands, East Nusa Tenggara Province has five islands, West Nusa Tenggara Province has one island, and North Maluku Province has one island.

Law Number 23 of 2014 concerning regional government's elucidation has determined the characteristics of archipelagic provinces. In the elucidation of the law, it is defined that a Province with Archipelagic Characteristics is a province area with geographical characteristics. ${ }^{27}$ Moreover, it is also an ocean area more comprehensive than the land in which some islands form a group of islands to become a geographical and socio-cultural unit. If it is further detailed, the character of an archipelagic province in this law is based on geographical characteristics. The character shows where the ocean area is wider than the land in which some islands form a group of islands. ${ }^{28}$ It becomes a geographical unit and cultural characteristic where the archipelagic province has socio-cultural ties. ${ }^{29}$

Based on the above considerations, the researcher believes that the archipelagic province criteria are not fully applied to determine the archipelagic province criteria. The criteria for an archipelagic state as a country consist of one or more islands. It may include other islands, where an archipelago is a group of islands, including parts of islands and the waters between these islands other natural forms that are related to each other. Others are so closely related that the islands, waters, and other natural features form an intrinsic geographical, economic, defense, and security, and political unit or are historically regarded as such. This criterion can only be applied to state entities given the attribute of sovereignty and jurisdiction over the territory by international law.

Meanwhile, in the archipelagic province, the priority criteria are geographical criteria. These criteria are based on the geographical specificity of the existing provinces. The researcher stated that the archipelagic provinces should not be based on essential economic, defense, security, and political factors or have historically been regarded as such as attributed to an archipelagic state. In addition, these criteria are specific to the state but can also threaten the Republic of Indonesia's unity because of its attributes. Such a country raises concerns

\footnotetext{
${ }^{27}$ Fauzi Janu Amarrohman et al., "Analisis Keberadaan Kepulauan Seribu Terhadap Batas Pengelolaan Laut Provinsi Dki Jakarta," Elipsoida 3, no. 1 (2020): 88.

${ }^{28}$ E. Djunarsjah and A. P. Putra, "The Concept of an Archipelagic Province in Indonesia," IOP Conference Series: Earth and Environmental Science 777 (2020): 1-2, https://doi.org/10.1088/1755-1315/777/1/012040.

${ }^{29}$ Cornelis Lay, "Desentralisasi Asimetris Bagi Indonesia," in Menata Ulang Desentralisasi Dari Perspektif Daerah (Yogyakarta: Program Pascasarjana Program Studi Ilmu Politik Fisipol UGM-USAID and DRSP, 2010), $1-2$.
} 
about the demand to become an economically, politically, security, and defenseless province from the Unitary Republic of Indonesia.

It is essential to mention that the aspirations of archipelagic provinces are based on the demand for special treatment from provinces. This particular treatment is in central and regional financial balance, which is based on calculating DAU and DAK by taking into account the area of the sea, nothing more than that. Thus, according to the researcher, the geographical and cultural criteria in Law Number 23 of 2014 above align with the basic concept of determining the archipelago province from the proposed provinces.

\section{Conclusion}

The international and national laws stated that the archipelagic state criteria could not be applied to mutatis mutandis. The archipelagic state as a geographical unit of economic, defense, and security and essential politics of which have historically been regarded as such and the 1982 UNCLOS and national legislation, cannot be applied in determining the criteria for an archipelagic province. The elucidation of Law Number 23 of 2014 explicitly states that the characteristics of an archipelagic province based on geographical and cultural conditions are a moderate concept for determining the characteristics of an archipelagic province.

\section{REFERENCES}

Amarrohman, Fauzi Janu, Moehammad Awaluddin, Bambang Darmo Yuwono, and Aisyah Arifin. "Analisis Keberadaan Kepulauan Seribu Terhadap Batas Pengelolaan Laut Provinsi Dki Jakarta.” Elipsoida 3, no. 1 (2020): 88.

Amerasinghe, C. F. "The Problem of Archipelagoes in the International Law of the Sea." International and Comparative Law Quarterly 23, no. 3 (1974): 541. https://www.jstor.org/stable/757887.

Benuf, Kornelius, and Muhamad Azhar. "Metodologi Penelitian Hukum Sebagai Instrumen Mengurai Permasalahan Hukum Kontemporer." Gema Keadilan 7, no. 1 (2020): 23. https://doi.org/10.14710/gk.7.1.20-33.

Budiarto, M. Wawasan Nusantara Dalam Peraturan Perundang-Undangan Negara Republic Indonesia. Jakarta: Ghalia Indonesia, 1980.

Djalal, Dino Patti. The Geopolitics of Indonesia's Maritime Territorial Policy. Jakarta: CSIS, 1996.

Djunarsjah, E., and A. P. Putra. "The Concept of an Archipelagic Province in Indonesia." IOP Conference Series: Earth and Environmental Science 777 (2020): 1-2. https://doi.org/10.1088/1755-1315/777/1/012040.

Hafandi, Muhammad Insan Tarigan Raisha. "Equal Access to the Vaccination of Covid-19 in Southeast Asia: Can ASEAN Be a Catalyst?" Hasanuddin Law Review 7, no. 2 (2021): 121. https://doi.org/10.20956/halrev.v7i2.2875.

Huda, Nikmatul. Desentralisasi Asimetris Dalam NKRI: Kajian Terhadap Daerah Istimewa, Daerah Khusus Dan Otonomi Khusus. Bandung: NusaMedia, 2014.

Hutagalung, Siti Merida. "Penetapan Alur Laut Kepulauan Indonesia (ALKI): Manfaatnya Dan Ancaman Bagi Keamanan Pelayaran Di Wilayah Perairan Indonesia." Jurnal Asia Pasific Studies 1, no. 1 (2017): 80. https://doi.org/10.33541/japs.v1i1.502.

Jaweng, Robert Endi. "Kritik Terhadap Desentralisasi Asimetris Di Indonesia." Jurnal 
Analisis CSIS 40, no. 2 (2011): 162. https://www.kppod.org/article/view?id=2.

Koesoemahatmadja, RDH. Pengantar Ke Arah Sistem Pemerintahan Daerah. Bandung: Binacipta, 1979.

Kusumaatmadja, Mochtar. Konsepsi Hukum Negara Nusantara Pada Konferensi Hukum Laut 1982. Bandung: Alumni, 2003.

Laksmana, Evan A., and Ristian A. Supriyanto. "Abandoned at Sea: The Tribunal Ruling and Indonesia's Missing Archipelagic Foreign Policy." Asian Politics \& Policy 10, no. 2 (2018): 305. https://doi.org/10.1111/aspp.12393.

Lay, Cornelis. "Desentralisasi Asimetris Bagi Indonesia." In Menata Ulang Desentralisasi Dari Perspektif Daerah, 1-2. Yogyakarta: Program Pascasarjana Program Studi Ilmu Politik Fisipol UGM-USAID and DRSP, 2010.

Manan, Bagir. Hubungan Antara Pusat Dan Daerah Menurut UUD 1945. Jakarta: Pustaka Sinar Harapan, 1994.

—. Menyongsong Fajar Otonomi Daerah. 5th ed. Yogyakarta: PSH FH UII, 2005.

Muhjidin, Atje Misbach. Status Hukum Perairan Kepulauan Indonesia Dan Hak Lintas Kapal Asing. Bandung: Alumni, 1993.

Nasional, Lembaga Pertahanan. Wawasan Nusantara: Naskah Sementara, Lemhanas. Jakarta, 2000.

Pandoyo, Toto. Wawasan Nusantara Dan Implementasinya Dalam UUD 1945 Serta Pembangunan Nasional. Jakarta: Rineka Cipta, 1994.

Pangkolnas, Sekretariat. Paparan Tentang Wawasan Nusantara (Pengakuan Perjuangan Dan Implementasinya). Jakarta: Departemen Pertahanan dan Keamanan RI, 1982.

Purwanto, Harry, and Dewa Gede Sudika Mangku. "Legal Instruments of the Republic of Indonesia in Border Management Using the Perspective of Archipelagic State." International Journal of Business, Economics and Law 11, no. 4 (2016): 55. https://www.ijbel.com/wp-content/uploads/2017/01/LAW-112.pdf.

Purwoko, Arief Adi. "The Material of Wawasan Nusantara as Indonesian Geopolitic Note and the Implementation in Islamic State University." At-Turats: Jurnal Pemikiran Pendidikan Islam 14, no. 1 (2020): 86. https://doi.org/10.24260/at-turats.v14i1.1785.

Rahmatunnisa, Mudiyati, Reginawanti Hindersah, and Tri Hanggono Achmad. "Why Regions with Archipelagic Characteristics in Indonesia Also Need Asymmetric Decentralization?" Jurnal Bina Praja 10, no. 2 (2018): 259. https://doi.org/10.21787/jbp.10.2018.251-261.

Risnain, Muh. "Rezim Provinsi Kepulauan Dalam Perspektif Negara Kesatuan Republik Indonesia, Wawasan Nusantara, Dan Otonomi Daerah." Unizar Law Review 3, no. 1 (2020): 103. https://e-journal.unizar.ac.id/index.php/ulr/article/view/247.

Rochwulaningsih, Yety, Singgih Tri Sulistiyono, Noor Naelil Masruroh, and Nazala Noor Maulany. "Marine Policy Basis of Indonesia as a Maritime State: The Importance of Integrated Economy." Marine Policy $108 \quad$ (2019): 2. https://doi.org/10.1016/j.marpol.2019.103602.

Soejito, Irawan. Hubungan Pemerintah Pusat Dan Pemerintah Daerah. Jakarta: Rineka 
Cipta, 1990.

Usman, Wan. "Wawasan Nusantara." In Lokakarya Wasantara Dan Tannas. Lemhannas, 2000.

Zainuri. "Pembentukan Hukum Dan Perlakuan Khusus Wilayah Provinsi Kepulauan Dalam Sistem Pemerintahan Daerah Di Indonesia.” Perspektif Hukum 18, no. 1 (2019): 86. https://doi.org/10.30649/ph.v18i1.

Zen, Bita Parga. "The Concept of Big Data Analysis for Maritime Information on Indonesian Waters Using K-Means Algorithm." Journal of Informatics, Information System, Software Engineering and Applications 3, no. 2 (2021): 44. https://doi.org/10.20895/INISTA.V3I2. 
 